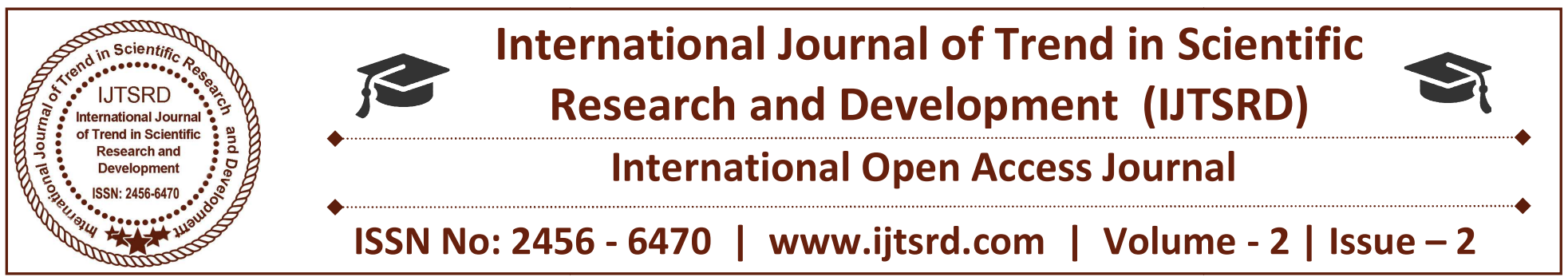

\title{
Analysis of the ICT user Profile for e-goverment through Bayesian Networks
}

\author{
Elia Martínez \\ Sierra Sur University, Maxico
}

\author{
Guillermo De la Torre-Gea \\ Sierra Sur University, Maxico
}

\section{ABSTRACT}

Since the use of information and communication technologies has now become indispensable for the development of human activity, governments have assumed the responsibility of ensuring access to them, as is the case in Mexico, generating a series of public policies aimed at that end. However, these politics have not generated the expected results since there are yet large differences to internet connectivity. This research presents an analysis of the availability and use of information and communication technologies. Diverse studies indicate that there is a verifiable inequality in terms of access to technologies, this difference is remarkable between municipalities and between regions. The analysis has allowed to know the main activities that the population makes through the ICT with the objective of determining the actions in matters of digital policies that must be considered by the local government. From the analysis performed it can be concluded that the majority of the population that Internet accesses does it through a desktop, laptop computer or a mobile phone. The most actions performed by the population through the internet are actions of entertainment and downloading software, as well as the search for general information, but participating in government affairs is not a priority issue. The population interested in public affairs is the one with the highest educational level, then that the institution requires the development of mechanisms to strengthen citizen participation in the taking of public affairs. It is also required to increase the communications infrastructure then that a greater percentage of the population can access the Internet. The programs on the use of technologies that must be developed by the government must be adapted. The study shows that the completion of procedures is not a priority issue, then that the implementation of electronic services may not have much impact on the Entity. It is necessary at first then to promote the development of the population's capacities to use of communication technologies. As a result, in this moment not have conditions to guarantee the success of an e-government policy such as the implementation of electronic payments and the use of mobile applications. It is necessary to overcome connectivity deficiencies and develop digital literacy actions to ensure the productive use of technologies.

Keywords: ICT, digital policy, user profile, connectivity.

\section{Introduction}

The considerable increase in the use of ICT information and communication technologies is now visible. However, a large number of people without access to these technologies, generating what is known as the digital divide. Governments have assumed responsibility for guaranteeing access to ICTs, as is the case of Mexico, generating a series of public policies to that end. However, these have not generated the expected results since there are currently large differences in access in Mexico.

The digital divide can be defined as the distance between those who have access to digital technologies and those who do not (Hilbert, 2011). The term refers, 
therefore, to an existing inequality between societies (Rodríguez, 2006; Serrano and Martínez, 2003). However, several authors add that when talking about digital divide the lack of access to technologies is not the only factor to analyze, but also it is necessary to include the use that the population gives to ICT. Consequently, there is also a cognitive gap, since technologies are not always used to obtain positive impacts on users' lives (Tello, 2008, Gómez, Calderón and Magán, 2008, Tarango, 2011, Grisales, 2011).

Regarding the case of Oaxaca, several studies indicate the perceptible difference in access to ICT. The National Survey on the Availability and Use of Information Technologies in the Households (INEGI, 2015) indicates that in the Federal District, Nuevo León, Sonora and Baja California, 6 out of 10 households have computers, in contrast to Guerrero, Oaxaca and Chiapas where less than a quarter of households have such technology. At the same time, in the first group of entities, 5 out of 10 households reported access to the internet, while in the second group, less than two out of ten households were reported.

For its part, the Center for Analysis for Innovation Research in its National Index of Science, Technology and Innovation 2015, places Oaxaca in 31 place in the field of information technologies. Even in cellular telephony, considering that it is more accessible, this difference persists. In this regard, in the states of Quintana Roo, Sinaloa, Baja California and Sonora, the proportion of use of this technology is over $80 \%$, while among the entities with the lowest user population of this technology is Oaxaca, Chiapas and Guerrero with $57.4 \%, 56.6 \%$ and $52.2 \%$ respectively (INEGI, 2015).

The above figures reveal the Institution's lagged situation compared to the other entities. In addition, there is a clear inequality within the State in terms of access to technologies. This difference is notable among municipalities and between regions, since Central valley's region presents greater access to technologies while the southern highlands and glen are among the lowest access levels (De la Torre-Gea et al., 2011). Considering the above conditions, the research presents an analysis of the availability and use of ICT in the State of Oaxaca.

\section{Method}

For the development of the study, the figures provided by the National Survey on the Availability and Use of ICT in Homes 2015 (INEGI) developed by the National Institute of Statistics and Geography (INEGI) are used. The variables selected were determined by the questions included in the survey. The variables related to the type of device used to access the Internet, the main activities that the population performs in the network, as well as general data regarding the sex, age and educational level of the users were chosen. Regarding the type of device through which users access the Internet, the variables described in TABLE 1 have been selected.

Table 1: Internet access through devices

\begin{tabular}{|c|c|c|}
\hline Variable & Code & Value \\
\hline Internet use & USO_INTERNET & 1 Yes \\
\hline \multirow{5}{*}{$\begin{array}{l}\text { Frequency of internet } \\
\text { usage }\end{array}$} & \multirow{5}{*}{ FRECUENCIA } & 1 Daily \\
\hline & & 2 Weekly \\
\hline & & 3 Monthly \\
\hline & & 4 Three months \\
\hline & & 5 With another lower frequency \\
\hline Hours of Access & HORAS_USO & 01-12 Hours per day using the Internet \\
\hline Device used & \multirow[b]{2}{*}{ COMPU_ES } & 1 Yes \\
\hline Desck top computer & & $2 \mathrm{No}$ \\
\hline \multirow{2}{*}{$\begin{array}{l}\text { Laptop, notebook or } \\
\text { Tablet }\end{array}$} & \multirow[b]{2}{*}{ LAP } & 1 Yes \\
\hline & & $2 \mathrm{No}$ \\
\hline
\end{tabular}


International Journal of Trend in Scientific Research and Development (IJTSRD) ISSN: 2456-6470

\begin{tabular}{|l|l|l|}
\hline Smartphone & \multirow{2}{*}{ MÓVIL } & 1 Yes \\
\cline { 3 - 3 } & & 2 No \\
\hline Smart TV & SMART_TV & 1 Yes \\
\cline { 3 - 3 } & & 2 No \\
\hline \multirow{2}{*}{ Video game console } & \multirow{2}{*}{ CONSOLA } & 1 Yes \\
\cline { 3 - 3 } & & 2 No \\
\hline
\end{tabular}

On the other hand, regarding the use that the Oaxacan population gives to the internet, the variables in Table 2 , obtained from the aforementioned survey, which include actions related to the government, were considered.

TABLE 2 shows that variables 11 to 16 refer to actions such as establishing communication with the government, consulting public information, downloading and sending public formats, as well as performing any other procedure or opinion in public matters.

Tabla 2. Internet usage

\begin{tabular}{|c|c|c|}
\hline Variable & Code & Value \\
\hline 01 To look for a job & U1 & 1 Yes/ 2 No \\
\hline 02 Send and receive emails & $y=\mathrm{U} 2$ & 1 Yes/ 2 No \\
\hline $\begin{array}{l}03 \text { Internet telephone } \\
\text { conversations (Voip) }\end{array}$ & $\mathrm{U} 3$ & 1 Yes/ 2 No \\
\hline 04 Create or visit blogs Inte & Thatu4nals & ournal 1 Yes/ 2 No \\
\hline 05 Keep a place of your own & U5 & $1 \mathrm{Yes} / 2 \mathrm{No}$ \\
\hline 06 Search general information & U6 & $1 \mathrm{Yes} / 2 \mathrm{No}$ \\
\hline 07 Support education & Resu7rch & 1 Yes/ 2 No \\
\hline 08 Online Banking & $\mathrm{U} 8$ & $1 \mathrm{Yes} / 2 \mathrm{No}$ \\
\hline 09 Entertainment & LeV U9 & 1 Yes/ 2 No \\
\hline 10 Download software & 10 & $1 \mathrm{Yes} / 2 \mathrm{No}$ \\
\hline $\begin{array}{l}11 \text { Communicate with the } \\
\text { government }\end{array}$ & SN:U11 & $1 \mathrm{Yes} / 2 \mathrm{No}$ \\
\hline $\begin{array}{l}12 \text { Consult government } \\
\text { information }\end{array}$ & $\mathrm{U} 12$ & $1 \mathrm{Yes} / 2 \mathrm{No}$ \\
\hline $\begin{array}{l}13 \text { Download government } \\
\text { formats }\end{array}$ & U13 & $1 \mathrm{Yes} / 2 \mathrm{No}$ \\
\hline $\begin{array}{l}14 \text { Fill out or submit } \\
\text { government formats }\end{array}$ & & $1 \mathrm{Yes} / 2 \mathrm{No}$ \\
\hline $\begin{array}{l}15 \text { Perform government } \\
\text { procedures }\end{array}$ & U15 & $1 \mathrm{Yes} / 2 \mathrm{No}$ \\
\hline $\begin{array}{l}16 \text { Opinion on government } \\
\text { inquiries }\end{array}$ & U16 & $1 \mathrm{Yes} / 2 \mathrm{No}$ \\
\hline 17 Access social networks & U17 & $1 \mathrm{Yes} / 2 \mathrm{No}$ \\
\hline $\begin{array}{l}18 \text { Order or buy products or } \\
\text { services }\end{array}$ & U18 & $1 \mathrm{Yes} / 2 \mathrm{No}$ \\
\hline 19 Sell products or services & U19 & $1 \mathrm{Yes} / 2 \mathrm{No}$ \\
\hline
\end{tabular}

The treatment of the selected variables was done through the use of the Elvira software, which is oriented to the edition and evaluation of Bayesian networks models and influence diagrams. Bayesian networks have different applications, for classification, prediction, diagnosis and provide relevant information on relationships between variables that can be interpreted as casusas and effects 
(Ortiz-Vazquez, et al., 2015; Sucar et al., 2014). In this sense, the relationships between three groups of variables are analyzed.

The first group is composed by the variables indicated in TABLE 1 referring to the type of device through which the Internet is accessed and its relationship with age, sex and educational level. The second group consists of the actions that users perform through the internet, are considered activities related to education, commerce and entertainment. The third group considers the variables that indicate actions related to the government and their relation with the sex, the age and the educational level of the population. population does not have access to data through this device.

In the same way, access through the mobile is related to age and educational level. Consequently, the greater the use of such devices, the greater the age, the lower the use of mobile phones and the higher the level of education

On the other hand, the variable related to the user's gender is the use of consoles, this is because the male population is the one that mostly connects to the internet through this medium. FIGURE 2 shows the relationships determined by the use of cell phones.

\section{Results and Discussion}

The results obtained from the treatment of variables related to internet access through various devices show that more than half of the population accesses the Internet and most of this access is given through a laptop, followed by access by Middle of a mobile phone.

There is a noticeable relationship between the use of desktop computer, mobile phone and laptop computer making them the most used devices. In this sense, users who do not access the internet through a desktop computer, do it through their cell phone. The relationships indicated are shown in Figure 1.

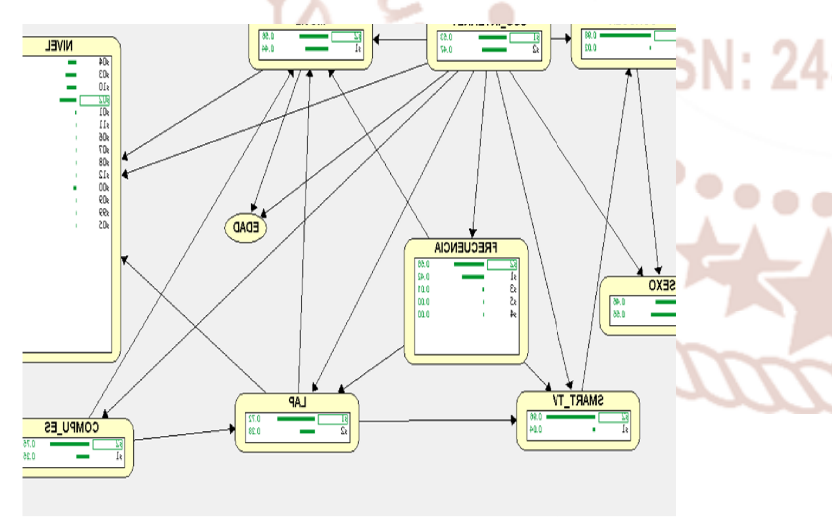

Figure 1: Internet access through devices

From Figure 1 it can also be derived that the most influenced variable is the one corresponding to the use of mobile phone, access to the internet through this device depends on the frequency, the use of other technologies such as the laptop and desktop. This can be determined by reason that if accessed through an internet computer it is no longer necessary to do then over the telephone or that the majority of the

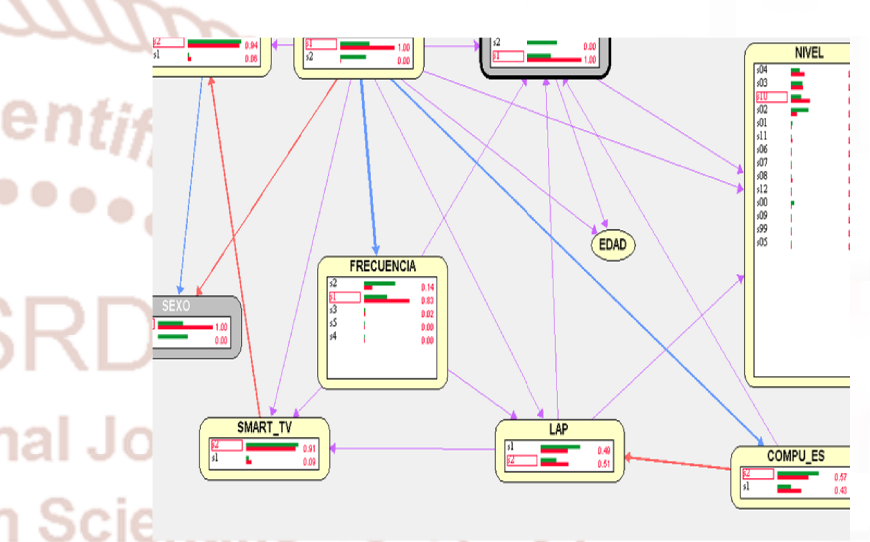

Figure 2: Inference of internet access through devices.

As for the population's use of the Internet, Figure 3 shows the relationships between the variables related to - this aspect. The variable that indicates the execution of bank transactions (U8) is negatively related to the one related to the purchase process (U18), the variables with the highest relations are those that indicate access to social networks (U17) and the download of Software (U10) influence in the same way, questions of information consultation (U6) and educational (U7).

The age variable is only related to access to social networks (U17), because as age increases, there is less access to this type of content. The people who access the social networks to a greater extent are the young people. On the other hand, the educational level is related to the variables (U2, U8 and U17) corresponding to the access to social networks, the use of electronic mail and entertainment actions, then that it can be deduced that the educational level does not Is determinant in the majority of the internet actions considered in this group of variables. 


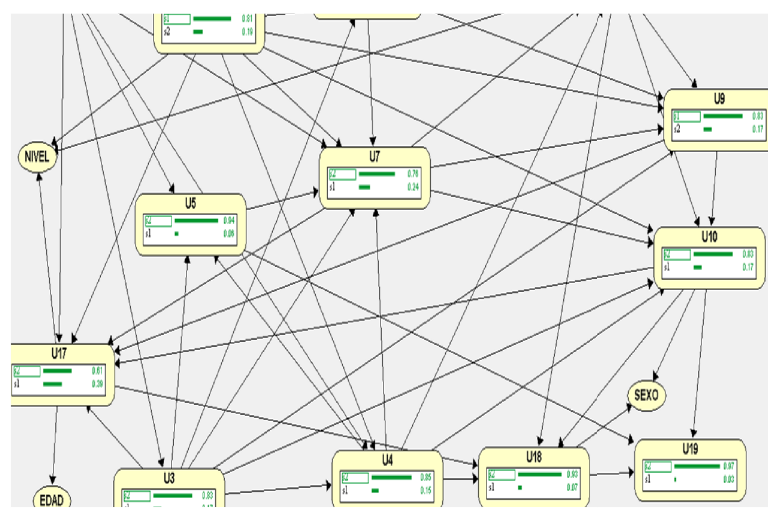

Figure 3: Internet use

From the previous figure also it is derived that the sex of the user, like the educational level, is not a determinant variable. This is because the only variables that keep a close relationship are the downloading of software and the making of purchases over the internet.

In order to analyze government-related activities (variables U11 to U16) and their relation to other variables such as the device through which the internet is accessed, the user's sex and age, as well as the educational level, have developed the network of Figure 4.

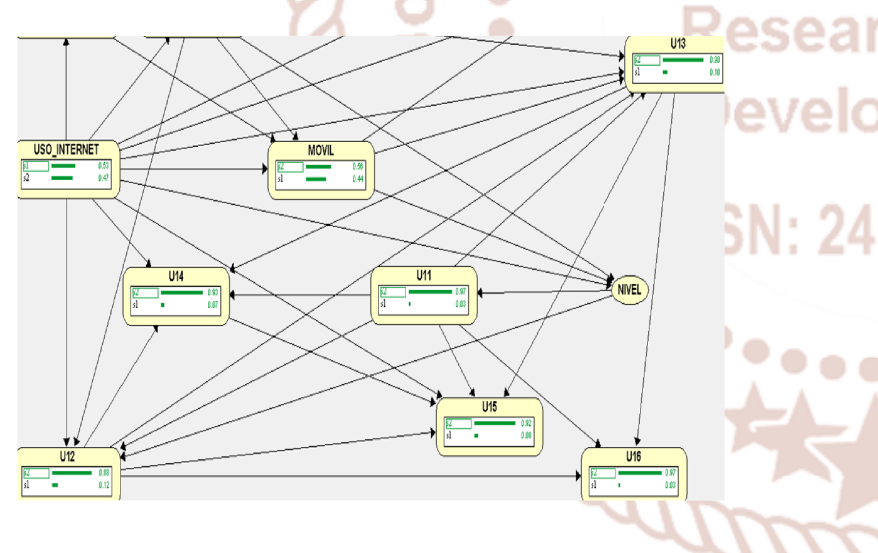

Figure 4: User activity related to government.

Figure 4 shows that the educational level, unlike the previous groups, does influence the performance of activities related to the government. The main variables that influence the educational level are to establish communication with the government and request information from the government. This is because researchers conducting studies related to public affairs make up the population that most requests information.

The variables U12 and U13v corresponding to the information request and to the download of formats are the variables most influenced by the others, because a suitable device is required to perform the file download. In the same way, downloading a format probably implies the execution of a request that requires it to be returned then that the variable $\mathrm{U} 13$ is related to the U14 corresponding to the sending of files.

As for age, this is not decisive in the performance of government activities since, as in the Figure 2 network, it is only related to Internet access and the use of mobile phones.

The variable U16 is the one with the lowest relation and corresponds to the use of the internet to participate in public consultations. In this sense, it can be deduced that the population is not interested in participating in this aspect.

\section{Conclusion}

From the analysis performed it can be concluded that in Oaxaca the majority of the population that accesses the Internet does it through a desktop or laptop computer or a mobile phone. The most actions performed by the population through the internet are actions of entertainment and downloading of software, as well as the search for information in general, then participating in government affairs is not a priority issue for the population. The population interested in public affairs is the one with the highest educational level, then that the institution requires the development of mechanisms to strengthen citizen participation in the taking of public affairs. It is not only a question of getting people involved but of taking their opinions into account then that the population observes the results of their participation.

It is also required to increase the communications infrastructure then that a greater percentage of the population can access the Internet. The programs on the use of technologies that must be developed by the government must be adapted to the uses of the population. The study shows that the completion of procedures is not a priority issue, then that the implementation of electronic services may not have much impact on the Entity. It is necessary at first then to promote the development of the population's capacities through the use of ICT, then that the population increases their confidence in the use of these and a future public e-government policy has the expected success. 
As a result, Oaxaca's society does not have the necessary conditions to guarantee the success of an egovernment policy such as the implementation of electronic payments and the use of mobile applications. It is necessary to overcome connectivity deficiencies and develop digital literacy actions to ensure the productive use of technologies.

\section{References}

1. Centro de Análisis para la Investigación en Innovación. (2015). Índice Nacional de Ciencia, Tecnología e Innovación 2015. México: CAIINNO.

2. De la Torre-Gea, G., Soto-Zarazúa, G., GuevaraGonzález, R., \& Rico-García, E. (2011). Bayesian networks for defining relationships among climate factors. International Journal of Physical Sciences, 6(18), 4412-4418.

3. Gómez Hernández, José Antonio Calderón Rehecho ; Antonio and Magán Wals, José Antonio. (2008). Brecha digital y nuevas alfabetizaciones. El papel de las bibliotecas. Biblioteca de la Universidad Complutense de Madrid. ISBN: 978-84-691-3466-5.

4. Gómez, J; Calderón, A y Magán, J. (2008). Brecha digital y nuevas alfabetizaciones. El papel de las bibliotecas. España: Universidad Complutense de Madrid.

5. Grisales, N. (2011). La brecha cognitiva: una realidad educativa que va más allá de la brecha digital entre las instituciones urbanas y rurales de Manizales. Revista Latinoamericana de Estudios Educativos (Colombia), 7 (2), julio-diciembre, 2011, 37-56. Universidad de Caldas, Manizales, Colombia.

6. Hilbert, M. (2011). The end justifies the definition: The manifold outlooks on the digital divide and their practical usefulness for policymaking. Telecommunications Policy, 35(8), 715736.

7. INEGI National Institute of Statistics and Geography. (2015). National Survey on Availability and Use of Information Technologies in Homes, 2015. México.
8. Márquez, A; Acevedo, J y Castro, D. (mayo, 2016): La brecha digital y la desigualdad social en las regiones de Oaxaca, México. Observatorio de la Economía Latinoamericana. Recuperado de http://www.eumed.net/cursecon/ecolat/mx/2016/d esigualdad.html

9. Ortiz-Vazquez IC, Pérez-Robles JP, FernandezLoyola R, Pérez-Brito JF, De La Torre-Gea GA. A multivariable computational fluid dynamics analysis method based in Bayesian networks applied in a bioreactor. Journal of Applied Chemical Science International. 2015;6(1):10-17.

10. Rodríguez, A. (2006). La brecha digital y sus determinantes. México: UNAM. Centro Universitario de Investigaciones Bibliotecológicas.

11. Serrano, A y Martínez, E. (2003). La brecha digital. Mitos y realidades. Baja California, México: Universidad Autónoma de Baja California.

12. Sucar, L.E.; Bielza, C.; Morales, E.F.; HernándezLeal, P.; Zaragoza, J.H.;. Larrañaga, P. (2014). Multi-label Classification with Bayesian Network based Chain Classifiers. Pattern Recognition Letters 41: 14-22. ISSN: 0167-8655.

13. Tarango, J., Marzal, M.A. (2011). Funcionalidad de la alfabetización informativa y sus ámbitos de actuación: aproximaciones a los entornos mexicanos y españoles. Revista Interamericana de Bibliotecología, Vol. 34, No. 3.

14. Tello, E. (2008). Las tecnologías de la información y comunicaciones (TIC) y la brecha digital: su impacto en la sociedad de México. Revista de Universidad y Sociedad del Conocimiento, 4 (2), 1-8.

15. Wang S, Li X, Tang H. Learning Bayesian networks structure with continuous variables. In $\mathrm{Li}$ et al. (eds). Lecture Notes in Computer Science, Heidelberg: Springer-Verlang. 2006; 448-456. 